\title{
アメリカンフットボール練習時のヘルメット温度と鼓膜温度の関係
}

\author{
石垣 享 ${ }^{1 ｝ \text { 藤城仁音 }{ }^{2} \text { 辻田純三1）圓 吉 } \text { 夫 }^{3}$ \\ 大和 眞 ${ }^{4)}$ 中野昭 - ${ }^{2)}$ 堀 清 記 ${ }^{1)}$
}

\section{RELATIONSHIP BETWEEN HELMET TEMPERATURE AND TYMPANIC TEMPERATURE DURING AMERICAN FOOTBALL PRACTICE}

\author{
Tohru Ishigaki, Hitone Fujishiro, Junzo Tsujita, Yoshio En, \\ Makoto Yamato, Shoichi NaKano and Seiki Hori
}

\begin{abstract}
Purpose : The purpose of this study was to examine the relationship among helmet surface temperature (Thl), head top temperature (Thd) and tympanic temperature (Tty) during American football practice in summer. Methods: The subjects were collegiate American football players. Temperatures were measured in August in 1993 and 1994. Thl, Thd and Tty were measured by infrared tympanic thermometers. Environmental temperatures that were measured were dry-bulb temperature $(\mathrm{Td})$, wet-bulb temperature (Tw), globe temperature (GT) and wet-bulb globe temperature (WBGT). Results : Significant correlations were observed among all measured temperatures $(\mathrm{P}<0.0001)$. High coefficients of correlation were observed among Thl, Thd and GT. The highest relationships were observed between $\mathrm{Thl}$ and $\mathrm{Thd}(\mathrm{r}=.727)$, and between Tty and $\mathrm{Td}(\mathrm{r}=.766)$. The coefficient of correlation between Tty and Thl was higher than that between Tty and Thd. Heat stress of the whole body (F 1 ; heat stress factor : Tty, Td, Tw and WBGT, proportion $=71.4 \%$ ) and head environment factor (F 2 ; helmet factor : Thl, Thd and GT, proportion $=14.3 \%$ ) were chosen in factor analysis. A close relationship was observed between both factors $(r=.773)$. Both GT and Thl showed a high correlation with Thd, which suggests the influence of radiant heat through a helmet on the whole body. Conclusion: The temperature in a helmet is a micro environment temperature surrounding the head. Accordingly, the heat load is reduced by taking the helmet off frequently during football practice.
\end{abstract}

(Jpn. J. Phys. Fitness Sports Med. 2001, $50: 333 \sim 338$ )

key word : American football, Tympanic temperature, Helmet temperature, Environmental temperature

\section{I. 緒}

アメリカンフットボール (以下フットボール)

は，米国および日本において夏季練習中の熱中症 による死亡事故が数多く発生したスポーツであっ $た^{1,2)}$ 。近年，米国においては $\mathrm{NCAA}^{3)}$ ，日本に

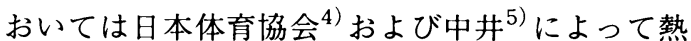
中症予防のガイドラインが示され，水分摂取等の 奨めにもより死亡事故は減少傾向にある。中井 ${ }^{5)}$ は，高温多湿となる日本の夏季フットボール活動 において環境温度の指標以外に練習日程, 着衣そ して水分補給についての対処方法を提示してい
1) 兵庫医科大学 生理学 第一講座 下663-8501 西宮市武庫川町1-1

${ }^{2)}$ 日本体育大学 大学院 体育科学研究科 健康科学・スポーツ医科学系 个158-8508 世田谷区深沢7-1-1

3) 日本体育大学 体育研究所 厂158-8508 世田谷区深沢7-1-1

${ }^{4)}$ 日本体育大学 運動生理学研究室 T158-8508 世田谷区深沢7-1-1
Department of Physiology, Hyogo College of Medicine, 1-1, Mukogawa-cho, Nishinomiya 663-8501

Research Institute of Physical Education, Nippon Sport Science University, 7-1-1, Fukasawa, Setagaya-ku 158-8508

Department of Sports Physiology

Graduate school of health and sport science 
る、本来フットボールは, 暑熱環境下での練習を 避けるべきであるが，日米共にリーグ戦の開始時 期は 9 月の第 1 週前後であるため夏季の練習をキ ヤンセルすることは困難であり，この時期に高強 度の練習も当然ながら必要とされる。よってフッ トボールは，十分な暑熱対策をしても熱中症が発 生する可能性が高いスポーツと考えられる.

フットボールは激しいコンタクトスポーツであ り，この衝撃から身体を守るために防具を装着す るのが特徴的である ${ }^{6)}$.この防具は，衝撃に対す る物理的な強度が優先されるため，身体からの熱 放散に関してはほとんど考慮されていない2)。さ らにフットボールは，ユニフォームにより体表面 の大部分を覆い隠すため熱放散の妨げも大きく， さらに防具の重量も生体に大きなストレスを及ほ すこととなる2).フットボールのユニフォームは, 1981年に熱放散を考慮して通気性のあるメッシュ の素材を用いるようになった7)。それに対してへ ルメットは，耐衝撃性が重要であり熱放散に関し ては全く考慮されていないのが現状である。ささら に主として比熱の低いプラスチック素材を用いて いるヘルメットは，外環境の影響を受け易いと考 えられるため頭部の温熱負荷をより一層増大させ る可能性がある.

そこで本研究は, 夏季フットボール練習中の鼓 膜温とヘルメット表面温および環境温度との関連 から，ヘルメットの温度が深部体温上昇に関わる 要因となるのかについて検討した.

\section{II. 方法}

\section{A. 被験者, 調查場所および期間}

被験者は, 関東大学アメリカンフットボール連 盟 1 部リーグに所属する日本体育大学アメリカン フットボール部の選手とした. 調査場所は, 長野 県にある軽井沢総合運動場であり, 調査期間は 1993年が 8 月11 21日, 1994年が 8 月 2 日 日で あった。

\section{B. 身体各部位の温度測定}

ヘルメット表面温 (Thl), 頭頂部温 (Thd)およ び鼓膜温 (Tty) の測定には, 赤外線温度計
(FirstTemp, Intelligent Medical System, CA, USA) 2 台を用いた。 Thl および Thd の測定には 1 台 のファーストテンプを表面温度測定モードに固定 し, Tty の測定にはもう 1 台を鼓膜温測定モード に固定しそれぞれ実施した。なお，赤外線鼓膜温 度計による測定は, 測定者の手技により測定值の 変動が大きいため8) 熟練した 2 名の者が行った。 Tty の測定は，プローブで耳管が完全に塞がれる 状態までプローブを指入した，Thl および Thd は，測定ブロープを被検部に直接接触させて測定 した. 温度測定は, 各練習セッション終了後直ち に被験者のヘルメットを脱がせ Thd (両側の耳管 を垂直に延長した頂点)および Tty を同時に測定 し，Thd 測定終了後にThl を測定した。なお温 度測定は, 測定機器および被験者への日射の影響 を考虑して遮光した条件で行った。

\section{C. 環境温度の測定}

調査場所の環境温度測定は, 身体各部位の温度 測定の15分以前から実施した。環境温度は, アス マン通風乾湿計と 6 インチ型の黒球温度計およ び黒球湿球温度計 (WBGT-101, 京都電子工業, 京都)を用いて, 乾球温度 $(\mathrm{Td})$, 湿球温度 $(\mathrm{Tw})$, 黒球温度 (GT) およびWBGT を計測した。

\section{D. 統計処理}

統計処理は, マッキントッシュ用統計ソフト 「Statview - 5.0」を用いた。実験期間中に観測 された全温度間の相関関係を算出した．生体への 温熱負荷に関わる因子の抽出には, 主成分分析を 用いた．主成分分析では，因子間の固有値との差 が相対的に高値を示す因子を採用し，因子軸の回 転はバリマックス法で行った。全統計処理におけ る有意差判定は，危険率が $5 \%$ 以下をもって有意 とした。

\section{III. 結果}

\section{A. 実験期間中に観察された各温度}

観察された各温度の平均および標準偏差を表 1 に示した．観測された環境温の中でも $\mathrm{Td}, \mathrm{Tw}$ お よび WBGT は, 非常に狭い範囲の変動であった 
Table 1. Observed temperature $\left({ }^{\circ} \mathrm{C}\right)$ during experiment.

\begin{tabular}{ccccc}
\hline & Mean & SD & Range & Median \\
\hline Thl & 33.58 & 4.27 & $21.5-42.2$ & 37.5 \\
Thd & 37.16 & 1.11 & $34.2-39.8$ & 38.0 \\
Tty & 37.92 & 0.72 & $35.9-40.0$ & 37.5 \\
& & & & \\
Td & 28.16 & 5.01 & $17.8-36.8$ & 27.8 \\
Tw & 23.21 & 3.00 & $17.4-31.8$ & 22.4 \\
GT & 36.56 & 6.71 & $19.5-46.5$ & 42.5 \\
WBGT & 26.38 & 3.42 & $18.1-31.7$ & 21.5 \\
\hline
\end{tabular}

Thl : Helmet surface temperature, Thd : Head top temperature, Tty : Tym. panic temperature, Td : Dry-bulb temperature, Tw : Wet-bulb temperature, GT : Globe temperature, WBGT : Wet-bulb globe temperature.

が，GT の変動幅は非常に大きいものであった.

観察された Thl は環境温度と同様に大きな変 動を示したが, Thd およびTtyは, 変動幅が約 5 ํ以内の非常に狭い範囲であった.

\section{B. 観察された各温度間の相関関係}

観察された各温度間の相関マトリックスを表 2 に示した．観察された度数は196であり，全ての 温度間において危険率 $0.01 \%$ 以下の有意な相関関 係が認められた. Thl および Thd の相関関係は GT とが最も高く, Tw とのそれが最も低かった. Thl と Thd 間には, 相関係数.727の高い相関関 係が得られた. Ttyは，Td との相関係数が最も 高く, GT とのそれが最も低かった. Tty は, Thd よりも Thl と高い相関関係にあった.

\section{C. 生体への温熱負荷に関与する因子}

観察された温度の主成分分析の結果を表 3 に示 した。ここで抽出された因子は 2 つであり，F 1 の固有值が $4.995, \mathrm{~F} 2$ の固有值が 0.999 であっ

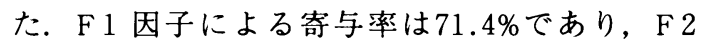
を加えた両因子の寄与率は $85.7 \%$ と高い割合であ ったＦ１は，Tty，Td，Tw およびWBGT が高い 因子負荷量であるため生体全体の温熱負荷に関わ る因子と考えられ，F 2 は Thl, Thd および GT が高い因子負荷量であるため輻射熱を介した頭部 の温熱負荷を示していると考えられる，両因子間 の相関係数は, .773 と高值であるため両者間に 密接な関係が認められた。

Table 2. Correlation matrix among observed temperature.

\begin{tabular}{c|cccccc}
\hline & Thd & Tty & Td & Tw & GT & WBGT \\
\hline Thl & .727 & .625 & .691 & .480 & .767 & .696 \\
Thd & & .533 & .514 & .326 & .613 & .516 \\
Tty & & & .766 & .698 & .502 & .732 \\
Td & & & & .876 & .713 & .964 \\
Tw & & & & & .431 & .911 \\
GT & & & & & & .762 \\
\hline
\end{tabular}

$\mathrm{n}=196$, All correlation were $\mathrm{p}<0.0001$.

Thl : Helmet surface temperature, Thd : Head top temperature, Tty : Tym. panic temperature, Td : Dry-bulb temperature, Tw : Wet-bulb temperature, GT : Globe temperature, WBGT : Wet-bulb globe temperature. 
Table 3. Results of factor analysis.

\begin{tabular}{cccc}
\hline & \multicolumn{3}{c}{ Factors } \\
\cline { 2 - 3 } Variables & F 1 & F 2 & SMC \\
\hline Thl & .385 & .842 & .733 \\
Thd & .165 & .883 & .558 \\
Tty & .723 & .421 & .648 \\
Td & .873 & .435 & .997 \\
Tw & .964 & .121 & 1.000 \\
GT & .398 & .783 & 1.000 \\
WBGT & .876 & .445 & 1.000 \\
\hline Eigenvalue & 4.995 & 0.999 & \\
Proportion (\%) & 71.4 & 14.3 & \\
Cumulative proportion (\%) & 71.4 & 85.7 & \\
\hline
\end{tabular}

Thl : Helmet surface temperature, Thd : Head top temperature, Tty : Tympanic temperature, Td : Dry-bulb temperature, Tw : Wet-bulb temperature, GT : Globe temperature, WBGT : Wet-bulb globe temperature, SMC : Squared multiple correlation.

\section{N. 考穹}

\section{A．赤外線鼓膜温度計による体温測定}

鼓膜温は，脳内の体温調節中枢とされている視 床下部の温度を反映するとしており，体温調節を 考える際に脳温の指標として促えられている ${ }^{9)}$. この際の鼓膜温は, 鼓膜の下部前方 $1 / 4$ の場所に センサーを接触させ, 外耳道を密栓することで耳 管内に空気の出入りが無い状態で測定された温度 を示す ${ }^{10)}$. 本来なら本研究においても正確な接 触型サーミスターを用いて鼓膜温を測定すべきで あるが，運動現場での接触型鼓膜温度計による体 温測定は危険と判断されたために実施しなかっ た、スポーツにおける深部体温は, 熱射病等の緊 急時には直腸温であることが一般的である ${ }^{11)}$ が, 緊急を要さなければ体温測定方法としては一般的 とは思えない. それに対して赤外線鼓膜温度計は, 短時間に多人数の測定が非侵襲的に可能となるこ とから, 本研究の体温測定には赤外線鼓膜温度計 を用いた。

運動現場における赤外線鼓膜温度計による体温 測定は，環境温度 ${ }^{12)}$ または皮虐温 ${ }^{13)}$ の影響を受 けるために深部体温としての信頼性に欠けるとの 報告がある一方で, 高体温の判定には有用である とする報告もある ${ }^{14,15)}$. Yeo \& Scarbough ${ }^{16)} に$
よると, 実験室内で運動前中後の体温を赤外線鼓 膜温度計によって測定した値は，同時に測定した 水銀直腸温度計の值より常に低値を示し, 体温上 昇を捉えることが不可能であった。 また Roth た ち ${ }^{17)}$ は，マラソン競技でメディカルケアを受け たランナーの直腸温と赤外線鼓膜温度計による測 定値との間に有意な相関関係は認められるもの の, 鼓膜温による高体温判定には問題があるとし ている.このように運動現場での赤外線鼓膜温度 計による体温測定を疑問視する報告も認められる 一方で, WBGT $36.5^{\circ} \mathrm{C}$ の暑熱環境下における運 動では，赤外線鼓膜温度計による測定值はサーミ スターで測定されたそれと高い相関関係にあり， 運動中の体温測定には有用であるとの報告もなさ れている ${ }^{18)}$. 赤外線鼓膜温度計のほとんどが屋 外で使用するために開発されたものでは無いた め, スポーツ現場では本来の使用目的とは異なっ た使用状況となる，現在，赤外線鼓膜温度計には 多くの機種が存在することから, 測定値の評価は 機種の特性によっても異なるものと考えられる。 この様な背景からも, 赤外線鼓膜温度計の測定値 を深部体温とするには疑問が残るが, 本研究の視 点は, 屋内の実験室では無く, 屋外の運動現場で 実際に測定可能である深部体温の指標として赤外 線鼓膜温度計による鼓膜温を採用した。 
B. ヘルメット表面温および鼓膜温に影篇を及 ぼす外的要因

深部体温の指標となる Tty は, Td, Tw および WBGT との間に高い相関関係が認められおり， 主成分分析においてもこれらは同一因子として抽 出された。この因子は, 全身の温熱負担を表して いると考えられ，暑熱ストレス全体の約 $70 \%$ の寄 与率であった，従って輻射熱に関係なく環境温度 の上昇は，深部体温を上昇させる大きな要因であ ることが理解される。これに対して, 本研究で観 察された Thl に強く影響を与えていたのは, へ ルメットに直接接している Thd と輻射熱の指標 となるGTの両者であった。主成分分析による 結果からも Thl, Thd および GT は, 頭部表面の 温熱環境の因子であると考えられる。 そこで夏季 フットボールには, 頭部のミクロ環境が存在する こととなる．頭表部とヘルメットの間は，ほとん どが空間部であるが一部パッドを介して接してい るため，両者間に伝導および放射による熱交換が 行われている事は十分に考えられる．頭表部とへ ルメット間の温度勾配は, 体温と輻射熱によって 変動するものと考えられることから，日射量の多 い時ではヘルメットが常に頭部表面を暖める状態 になり，生体に及ほす温熱負荷量を増加させるこ ととなる。従って環境温度の中の輻射熱は, 直接 深部体温を上昇させる因子ではなく，ヘルメット を介して頭部を暖めるものと考えられる。本研究 の結果から, Thl および Thd の頭部の温度は, Tty に直接大きな影響を与えることはないと思わ れるが, 生体への暑熱ストレスを避けるためには 考慮すべき外環境となる.

ヘルメット自体の温度では無くヘルメットの着 用が, 高体温を引き起こす要因ともなる，高体温 時の Tty の変動には, 他の深部体温(直腸温また は食道温)とは異なる体温調節機構である選択的 脳冷却機構 (SBC) が存在する ${ }^{19}$. 。体幹部と異な り脳においてこのような機構が存在する意義は, 脳が熱に最も弱い器官であり，長時間にわたる異 常高体温(熱射病) は神経系の障害を引き起こすこ とからも理解される ${ }^{20)}$. SBCの機能は, 頭表面 からの汗の蒸発または鼻腔および上気道からの熱
放散の増加に依存する ${ }^{21)}$. ヒトに温熱負荷をし た際の鼓膜温および前額部からの発汗量は, 充分 な水分補給をした状態と脱水状態では変化が認め られなかったが, 背中からの発汗は脱水状態で大 きく低下した報告がなされている ${ }^{22)}$ 。この報告 からも, 脳を冷却するための頭部からの発汗は体 幹からのそれに比べて非常に重要であり，ここで の有効発汗の低下は脳温上昇を招くと解される. SBC は, 冷却された頭表面の血液が頭頂導出静 脈を経由し直接脳を冷却するため, 頭表面の冷却 は脳温を低く保つためには重要なことである ${ }^{21)}$. 頭部の覆いの有無と運動強度が鼓膜温に及ほす影 響を検討した Rasch \& Cabanac ${ }^{23)}$ の報告による と, 運動強度の増加につれ帽子を被らない被験者 の鼓膜温は食道温よりも有意に低值であるのに対 し，帽子を着用した場合ではこれら両者間に有意 な差が認められず, SBC が減弱する事が示され ている。この報告からも, 頭頂部を覆うことは必 要以上に Tty を上昇させる要因となりうる. 従っ てフットボール中のヘルメット着用は, 熱放散も 大きく抑制される上に, 頭部からの発汗のほとん どが無効発汗になることは十分にありえる．さら に永坂たち ${ }^{24)}$ の報告によると，ヒトに暑熱負荷 した際の導出静脈の血流を抑制することによって 鼓膜温が上昇することから, ヘルメット内部のパ ッドによる頭部圧迫により導出静脈の血流が阻害 されることでTty が上昇する可能性が示唆され ている.ただし本研究では, 頭頂導出静脈の温度 および血流量または血流方向を測定しているわけ ではなく, あくまで推察である。この様な生理学 的な検討によってもフットボールにおけるへルメ ットは，体温を上昇させる要因であることには間 違いない.フットボールにおいて脳温または体温 の上昇を防ぐには, ヘルメットは邪魔な存在とな る.そこで, 暑熱環境下でのフットボールは, 休 息中にヘルメットを脱ぎ, 肌の露出を多くするこ とが鷹められている ${ }^{2)}$ が, 本研究の結果からもへ ルメットを脱ぐ機会は多く作るべきである事が理 解される。

フットボールにおけるヘルメットの温度は, 日 射による輻射熱を頭部に伝えていることが判明し 
た. 従って，フットボールの練習中に頻繁にヘル メットを脱ぐことは, 頭部への温熱負荷 (輻射熱) を低減させる効果と SBC を十分に働かせる効果 を併せ持つと考えられる。

\section{辢 辞}

本研究に対して献身的に協力して頂いた日本体育大 学アメリカンフットボール部 ゴールデンベアーズの 選手の皆さんに心より感謝の意を表します。

（受理日 平成13年 2 月19日）

\section{引 用 文 献}

1）川原 貴. アメリカンフットボールにおける重大 事故の統計的観察, 臨床スポーツ医学, (1995), 12, $1-4$.

2) McArdle, M. D., K. L. Katch, and V. L. Katch. Exercise physiology-Energy, Nutrition, and Human Performance- . Lea \& Febiger, Philadelphia, (1991), 547-579.

3) National Collegiate Athletic Association. Prevention of heat illness. In Earle, M. V. (Eds.), NCAA Sports Medicine Guidelines, 11 th Ed., (1998), 18-20.

4）日本体育協会. スポーツ活動中の熱中症予防ガイ ドブック，日本体育協会，(1999），2-47.

5) 中井誠一. 高温環境とスポーツ種目別の暑さ対 策：アメリカンフットボールの暑さ対策, 臨床ス ポーツ医学, (1997), 14, 763-768.

6) 石垣 享, アメリカンフットボール, トレーニン グの科学「エンデュランストレーニング」, 朝倉書 店, 東京, (1994), 97-102.

7) Cain, T. E., B. Donzis, and J. Meins, Use of the airinflated jacket in football. Am. J. Sports. Med., (1981), 9, 240-243.

8）坂田義行, 渡辺達生, 中村知毅. 耳式体温計によ る鼓膜温測定手技の検討. 新薬と臨床, (1994), 43, 2011-2018.

9) Mariak, Z., J. Lewko, J. Luczaj, B. Polocki, and M. D. White. The relationship between directly measured human cerebral and tympanic temperatures during changes in brain temperatures. Eur. J. Appl. Physiol., (1994), 69, 545-549.

10) Brinnel, H., and M. Cabanac, Tympanic temperature is a core temperature. J. Thermal. Biol., (1989), 14, 47-53.
11) American College of Sports Medicine. Heat and cold illnesses during distance running, position stand. Med. Sci. Sports Exerc., (1996), 28, i-x.

12) Doyle, F., W. J. Zehner, and T. E. Terndrup. The effect of ambient temperature extremes on tympanic and oral temperatures. Am. J. Emerg. Med., (1992), 10, 285-289.

13) Roberts, W. O. Assessing core temperature in collapsed athletes. Phys. Sports Med., (1992), 22, 4955.

14）東澤知輝. スポーツ環境における体温・環境温の 測定と体温管理のポイント. 臨床スポーツ医学, (1999), 16, 1478-1483.

15）石垣 享, 小山勝弘, 武村政德, 賀屋光晴, 辻田 純三, 堀 清記, 山下陽一郎, 大和 畺, 藤城仁音. 夏季運動現場での鼓膜温と環境温との関係. 関西 臨床スポーツ医・科学研会誌, (1998)， 7, 53-55.

16) Yeo, S., and M. Scarbough. Exercise-induced hyperthermia may prevent accurate core temperature measurement by tympanic membrane thermometer. J. Nurs. Meas., (1996), 4, 143-151.

17) Roth, R. N., V. P. Verdile, L. J. Grollman, and D. A. Stone. Agreement between rectal and tympanic membrane temperatures in marathon runners. Ann. Emerg. Med., (1996), 28, 414-417.

18) Bricknell, M. C. An evaluation of infra-red tympanic thermometry for thermal physiology research. J. R. Army Med. Corps., (1997), 143, 149-152.

19) Cabanac, M. Slective brain cooling in humans: "fancy" or fact?. FASEB J. (1993), 7, 1143-1147.

20) Siminia, P., J. Haveman, and B. W. Ongerboer DeVisser. What is a safe heat dose which can be applied to normal brain tissue? Int. J. Hyperther. (1989), 5, 115-116.

21) Cabanac, M., and H. Brinnel, Blood flow in the emissary veins of the human head during hyperthermia. Eur. J. Appl. Physiol. (1985), 54, 172-176.

22) Caputa, M., and M.Cabanac, Precedence of head homoeothermia in dehydrated men. Eur. J. Appl. Physiol., (1988), 57, 611-615.

23) ) Rasch, W., and M. Cabanac, Selective brain cooling is affected by wearing headgear during exercise. J. Appl. Physiol., (1993), 74, 1229-1233.

24) Nagasaka, T., M. Hirashita, M. Tanabe, S. Sakurada, and $\mathrm{H}$. Brinnel, Role of the veins of the face in brain cooling during body warming in human subjects. Jpn. J. Biometeor., (1990), 27, 113-120. 